\title{
"This is the biggest place where you can express your imagination": Information practices of middle school students at a school library makerspace
}

\author{
Xiaofeng Li, Ross J. Todd \\ Rutgers, The State University of New Jersey \\ 4 Huntington St, New Brunswick, NJ \\ USA, \\ xiaofeng.li@rutgers.edu, rtodd@rutgers.edu
}

\begin{abstract}
This study aims to understand what brought a group of middle students to their school library makerspace, their questions, information practices, and barriers in their participation. Informed by Dervin's sense-making verbing approach and sociocultural approaches to learning, qualitative data were collected through initial interviews, surveys, follow-up interviews, and weekly field observations over six months. The findings show that the school library makerspace was a social and informal learning environment for the students to have fun, be creative and develop skills in science, technology, engineering, mathematics and arts. Their information practices ranged from tinkering with materials and technologies, and getting help from interpersonal resources. This study highlights the information practices at the library makerspace were social in nature, embodied through materials and tools, and embedded in the formal educational system; this study also sheds light on the affordances and constraints of the materials and computers in the students' activities at makerspace.
\end{abstract}

Keywords: middle school students, information practices, school library makerspace, informal learning

\section{Introduction}

Makerspace was first promoted by Maker Media, the publisher of MAKE: magazines to celebrate the grass-roots American culture and do-it-yourself (DIY) projects in 2005. Since 2007, makerspaces have received a lot of interest and support from the government, research institutes, museums, libraries, and schools in the U.S. (Benton, Mullins, Shelley, \& Dempsey, 2013; Colegrove, 2013). To date, an increasing number of libraries, museums, universities 
embrace this maker movement and culture to design and implement makerspaces across the nation and the world (Benton et al., 2013).

A growing number of literature has investigated the outcome and benefits for school-aged students to participate in library makerspace activities (Fontichiaro, 2014; Gustafson, 2013; Koh, 2015). While makerspaces are designed to provide programs and resources that encourage people to learn about science, technology, engineering, and mathematics (STEM), and foster people's creativity and innovation with technologies (Colegrove, 2013; Graves, 2014), few studies have given attention to the opportunities that bring students to school library makerspaces and their information practices in these informal learning environments.

The research goal of this study is twofold. First, this study aims to develop a holistic understanding of information practices of a group of middle school students participating in playful and creative activities at school makerspace. Second, this study chooses the library makerspace as the operationalization of informal learning environment, with the goal to understand the roles of school library makerspaces in students' learning and development. This study will contribute to the growth of empirical research pertaining to young people's information practices in informal learning environments (i.e., library makerspace).

\section{Literature review}

\section{Library makerspaces - designed informal learning environments}

Library makerspaces have been characterized as social and informal learning sites in extant studies. These library makerspaces and programs are designed and implemented with the goal of providing people meaningful learning experiences, hands-on explorations and experiments in order to foster people to be entrepreneurial and creative, to pursue their interests as well as to collaborate with people coming with different levels of expertise and experiences (Benton et al., 2013; Bowler, 2014). Current descriptive studies on library makerspaces, show that people set their own learning agenda based on their curiosity and motivation (Fontichiaro, 2014), seeking information from sources more than teachers and textbooks beyond academic requirements (Gustafson, 2013; Koh, 2015), and developing ownership and leadership of their own production (Graves, 2014). These characteristics of makerspaces align with the nature of informal learning - essentially social, self-directed, interested driven and free-choice learning (Falk \& Dierking, 2000; Hsi, 2004).

\section{Young people's information needs, seeking, and use in everyday life}

Research on young people's everyday life information practices is closely relevant for this study to develop an understanding of the information phenomena in an informal setting, as everyday life information seeking (ELIS) is pertaining to making sense non-work related activities and non-imposed school tasks (Savolainen, 1995). A review of extant research on youth ELIS shows that young people have information needs not only regarding their school 
assignments but also their affective and physical aspects of lives (Agosto \& Hughes-Hassell, 2006).

Young people prefer seeking everyday life information through social relationships and their information seeking practices are essentially social (Dresang, Gross, \& Holt, 2003). Shenton and Dixon (2005) found that young people turn to adults and their peers for information. Agosto and Hughes-Hassell (2006) indicated that teens prefer consulting with friends and family. In line with these findings, Meyers, Fisher, and Marcoux (2009) highlighted the social and affective factors that foster information exchanging, sharing, and seeking. Frequently young people seek information from their peers directly or use computer-mediated communication (p.316). However, young people do not always actively seek information even when they have questions and uncertainties. Julien (1999) found that less than half of the adolescent participants engage in systematic and active information seeking to make career-related decisions. Most of the participants utilize their intuition, self-awareness, and feelings to guide them in looking up information pertaining to their future careers. Barriers that young people encounter in their everyday life information seeking include adults' control over media access, norms and expectations of certain behaviours and practices, lack of trust in authorities, institutional barriers such as school scheduling, and emotional factors (Julien; 1999; Meyers, Fisher, \& Marcoux, 2009).

\section{Theoretical framework}

In the field of library and information science, despite that research on information needs, seeking and use has shifted its attention from a system-oriented perspective to a user-centred approach since the 1980s (Dervin \& Nilan, 1986), much research in understanding information-related activities has been concerned with active and purposeful information seeking and use behaviours among professionals and formal educational settings. Yet, a true user-centred approach calls for a holistic understanding of the relationships between users and information (Julien, 1999; Olsson, 2010). In connecting to this line of research, this study draws upon a set of theories to create a hybrid theoretical framework, which incorporates Dervin's (1999) sense-making verbing approach and sociocultural approaches to learning, in particular, situated learning (Lave \& Wenger, 1991), embodied knowing (e.g., Shapiro, 2010), and distributed cognition (Hutchins, 1995).

\section{Sense-making verbing approach}

Over the years, Dervin's stance on her sense-making theory has evolved from a cognitive constructivist perspective to a "verbing" approach (Dervin, 1999) that gives theoretical attention to the social aspect of sense making (Olsson, 2010). Conceptualized from Dervin's verbing approach, information is a verb rather than a noun; it is "a structural term" (Dervin, 1999, p.738) that represents both the "product of and fodder for sense making and sense unmaking" (Dervin, 1998, p.36). A small number of studies in information research have 
employed this approach (e.g., Genuis, 2012; Godbold, 2013; Olsson, 2010). These studies suggest that information practices consist of more than active information seeking to satisfy one's information needs. Rather, practices represent complex and nonlinear processes that involve cognitive, affective, and physical dimensions, and are interwoven with situational, contextual, social, and cultural elements, such as norms and communities to which people belong.

\section{Sociocultural approaches to learning}

One influential learning theory that takes the stance of leaning as participation is Lave and Wenger's (1991) situated learning. Working from a sociocultural theoretical perspective of learning (e.g., Vygotsky, 1980), Lave and Wenger (1991) claimed that learning is realized through practice and participation within particular communities that develop over time through a process of "legitimate peripheral participation" (p.29). From this perspective, learning constitutes essentially situated activities, facilitated through social participation, and is an integral part of social practice in social world.

The notion of situated learning does not constrain learning as isolated to one place and time or dependent on an immediate social setting. Rather, it sheds light on the dynamic and dialectical relations between "'person', 'activity', 'knowing,' and the 'social world'” (Lave \& Wenger, 1991, p.122). It offers guidance in understanding learners as social actors and learning as social. This perspective further guides the conceptualization of a complex and dialectical context (Courtright, 2007) of information practices that this study intends to investigate. Through the lens of Lave and Wenger's communities of practice, information practices in which young people engage at informal learning environments are seen as an integral part of their social activities.

When humans and activities are conceptualized as situated, their experiences are inevitably embodied and co-constitutive (Lave, 1988; Wenger, 1998). Especially in the activities of design and creation, where people interact with materials, artefacts, and tools, designers work with things, imbue meaning to things, and explore and improve ideas using material forms (Hakkarainen et al, 2013). With theoretical attention to embodied ways of knowing, it may account for both individual sense-making and the sociocultural and material aspects of collaborative sense-making (Anderson, 2007).

Further, this study draws on the notion of distributed cognition to understand the roles of materials such as tools, objects, and artefacts as culturally mediated (Cole \& Engeström, 1993; Hutchins, 1995). Similarly, Lave and Wenger (1991) stated that tools and artefacts "carry a substantial portion of that practice's heritage" (p. 101), and should not be viewed at their face value, but rather as generated from cultural practices and social processes. Moreover, artefacts and tools are given a central role in mediating collaborative learning processes and in understanding collaborative knowledge creation (Hakkarainen et al, 2013). 
In addition to their material properties, objects can also be "epistemic, not having tangible or material form" (Hakkarainen et al, 2013, p.59). These shared epistemic objects could be conceptual ideas, hypothesis, or plans. Overall, this notion of distributed cognition gives theoretical attention to the roles of tools and objects, either in material or epistemic forms, in young people's information practices.

\section{A hybrid approach}

Based on abovementioned theories and concepts, this study applies a hybrid theoretical framework that reflects the interdisciplinary nature of information practices within informal contexts (Kincheloe, 2001). Overall, Dervin's sense-making verbing approach provides a lens to understand individuals' problem solving and inquiry across time and space. The sociocultural approaches to learning offer lenses to understand interactions, materials, and space, as well as the norms and cultures in which young people's information practices take place. Together, these lenses can support development of a holistic understanding of the information phenomena emergent in informal learning environments. Figure 1 shows a conceptual map that represents the synergy of the abovementioned theoretical approach to guide the investigation of this proposed study. The conceptual contribution of each element in this conceptual model is highlighted in Table 1, as well as the methodological considerations for this study.

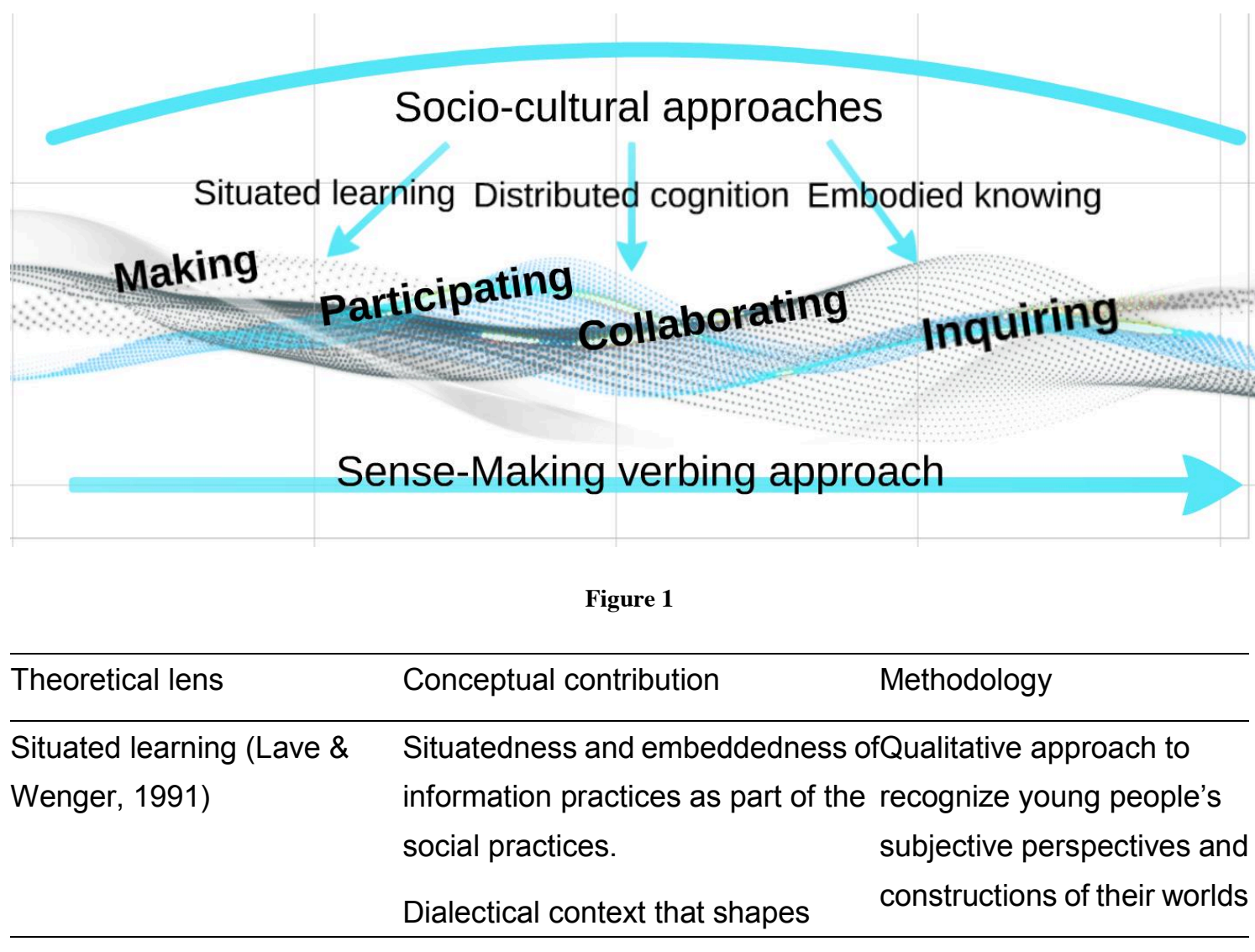




\begin{tabular}{|c|c|c|}
\hline & $\begin{array}{l}\text { practices and is also shaped by } \\
\text { practices; the relations between } \\
\text { acting persons and their immedia }\end{array}$ & $\begin{array}{l}\text { during their making, } \\
\text { participating, collaborating, } \\
\text { and inquiring (Creswell, }\end{array}$ \\
\hline & $\begin{array}{l}\text { constraints, including people, } \\
\text { materials, and space. }\end{array}$ & $\begin{array}{l}\text { 2003). } \\
\text { Observer as participant }\end{array}$ \\
\hline $\begin{array}{l}\text { Embodied knowing (Lave, } \\
\text { 1988; Shapiro, 2010) }\end{array}$ & $\begin{array}{l}\text { Actions and doings in relation to } \\
\text { material objects, tools, and } \\
\text { artefacts. }\end{array}$ & $\begin{array}{l}\text { field observations } \\
\text { (Kawulich, 2005). } \\
\text { Initial informal interviews }\end{array}$ \\
\hline Distributed cognition (Cole \& & The mediating role of shared & and follow-up interviews \\
\hline Engeström, 1993; Hutchins, & objects (including both tangible & informed by (Dervin's 1992) \\
\hline 1995) & $\begin{array}{l}\text { objects and conceptual artefacts) } \\
\text { collaborative activities. }\end{array}$ & $\begin{array}{l}\text { nsense-making interview } \\
\text { technique. }\end{array}$ \\
\hline $\begin{array}{l}\text { Verbing approach to } \\
\text { information practices (Dervin }\end{array}$ & $\begin{array}{l}\text { Situations in which problems or } \\
\text {,gaps occur, process of solving }\end{array}$ & $\begin{array}{l}\text { Sense-making survey } \\
\text { (Brendlinger, Dervin, \& }\end{array}$ \\
\hline 1999) & $\begin{array}{l}\text { problem and bridging gaps, } \\
\text { outcomes in a given situation. }\end{array}$ & Foreman-Wernet, 1999). \\
\hline
\end{tabular}

Table 1

\section{Research questions}

RQ1: What are the situations and opportunities that bring the students to engage in makerspace activities?

RQ2: What kinds of questions do the students have as they participate in makerspace activities?

RQ3: How do the students make sense of the encountered questions as they participate in makerspace activities?

RQ3.1: How do these informative resources help the students' making and participating?

RQ4: What barriers hinder the students from accessing resources needed as they participate in makerspace activities?

RQ4.1: How do these barriers hinder the students' participation?

\section{Methodologies}

\section{Research site}

The library makerspace in this study is located in a semi-rural public middle school in the Northeast of the States. The demographic of this school is $61 \%$ of White, $24 \%$ of Hispanic, $8 \%$ of Black and the rest are Asians and multi-races. According to the state standard test reports 
for grade 4 to 8 from 2013 to 2014, the academic performance of this school was high compared to other schools state-wide, and about average compared to similar school in the state.

This school's library makerspace offered a variety of programs to different grades, including: 1) gifted and talented program, 2) Maker Monday, 3) lower-school (4-5 grades) and upper-school (6-8 grades) technology clubs, 4) Lego mind storms, 5) brick buddies designed for a small group of $4^{\text {th }}$ grade students from the autism class and general classes, and 6) teacher-driven classes that use makerspace resources to learn about scales, electronic circuits, and language arts (e.g., sentence crafting, poetry).

Among all these programs, the technology clubs were selected because they met with the characteristics of informal learning. The students in the technology clubs were allowed to engage in "free-choice learning" (Falk \& Dierking, 2000, p.13). The technology clubs did not have assessments on participation and learning, and the students could decide when to participate, so it aligned with the characteristics of low consequence assessment and voluntary (Bell, Lewenstein, Shouse, \& Feder, 2009). The technology club also encouraged the students to collaborate with their peers and the teacher played the role of a facilitator. Both the lower- and upper- school technology clubs ran weekly on different days. This report focuses on the upper-school technology clubs.

\section{Data collection}

The data collection was carried out over six months from October 2015 when the technology club started to April 2016 when it ended. Parental and children consent forms were disseminated, signed, and returned before data collection proceeded. Given that this study adopts a hybrid approach based on a social constructivist approach and the sociocultural learning theories, qualitative methodologies and procedures were chosen to elicit the students' subjective perspectives of they made, participated and collaborated, and learned at the technology clubs in the library makerspace. Qualitative research is characterized as studying natural settings, using multiple interactive methods, and developing a holistic understanding of social phenomena (Creswell, 2003). These characteristics of qualitative research support the goals of this study and are compatible with the theoretical stance of this research.

Qualitative data were collected through three rounds of data collection, including: 1) nine semi-structured interviews, 2) eight Sense-Making surveys with open-ended questions, and 3) six follow-up semi-structured interviews. The interviews were informed by the Sense-Making time-line interview technique (Dervin, 1992, 1999). Following this technique, the participants were asked to construct their world and perspective step by step- how they define the gaps, what bring them to gaps, what questions they have, how they feel, how they are helped and hindered, and what consequences they have. To employ Sense-Makings interview method, researchers took the stance of "minimal intrusions and naming of the world" and the 
participants were treated as "information expert(s) and theorist(s)" (Dervin, 1999, p.740-742). The initial round of interviews was conducted between mid-November 2015. The follow-up interviews were conducted towards the end of the program in April 2015.

Sense-Making surveys were conducted in December 2015 to zoom in the challenging situations in their recent participation at the makerspace. The open-ended questions in the Sense-Making surveys allow the participants to freely describe their situations, information needs and its uses (Brendlinger, Dervin, \& Foreman-wernet, 1999). Informed by Dervin's Sense-Making theory and methodology, the survey contains three sections: step-by-step description of a challenging situation, specific questions raised during the situation, corresponding informative resources that they consulted, the results of how identified informative resources helped the students move forward with their participation at the makerspace.

Along with these three rounds of data collection, the first author took the role of "observer as participant" (Kawulich, 2005) and engaged in weekly observations at the library makerspace. The strength of participant observation includes building rapport with the participants and their community, helping the researcher to build a better understanding of what happens in a naturalistic setting and generating questions to be addressed with the participants and increase the validity and quality of data (Gans, 1999; Kawulich, 2005). Due to the nature of informal learning environments, the activities at the library makerspace were loosely structured, messy and discontinuous (Ash, 2007). Yet, following the strategies of "descriptive observation", "focused observation", and "selective observation" (Angrosino \& dePerez, 2000, p.677), the researcher started with descriptive observation when the activities started. As the participants' activities unfold, the researcher observed selected, attending to the sense-making moments when they raised questions, expressed confusions, and indicated challenges in their participation, as well as "significant events" that had clear beginning and ending, sustained interactions, and various resources (Ash, 2007, p.216).

\section{Data analysis}

All the interviews will be first transcribed. The transcripts and field notes were imported to Nvivo qualitative data analysis software. According to Miles, Huberman, \& Saldaña (2013), codes will first be created based on the elements of conceptual framework and research questions. After this stage, rounds of pattern coding were employed to reveal emerging themes and relations of the codes generated from the first round of coding. During the course of data analysis, the researcher wrote memos to reflect on theoretical notions and document any conflictive thoughts (Glaser \& Strauss, 1967; Miles, Huberman, \& Saldaña, 2013).

\section{Findings}


The findings depict the middle school students' routine activities and information practices at the school library makerspace. The findings are organized by the research questions.

\section{Opportunities of library makerspace}

Several themes pertaining to what brought the students to engage in the technology club at makerspace have emerged. The most common drive was the informal learning opportunities that the library makerspace offered, following which were long-time personal interests in engineering and technologies, identity development through participation, and convenience.

The most common term mentioned in their accounts about their informal learning experience at makerspace was "to have fun" because they got to work on computers, to do and build things with materials directly, to hang out with friends, to be creative and to do things that were different from their traditional classes. For example, one student indicated "I like working with computers and stuff and I love Legos, really fun and I like thinking about stuff so it kinda helps work my brain cause I feel like I gotta think more with Legos I got to imagine more."

The interviews and field observations show that working on computers mostly included coding, playing games, and designing 3D objects. These were fun because they could "do whatever I want" with online resources and the affordance of computers. One student commented, "It doesn't restrict you to do any certain things on the coding websites unless it asks for something." Another student explained, "I usually go to the computer because it gives more things to do on the computer than with the other things."

It also shows that the students had fun as they had access to different tools and materials at makerspace, and they enjoyed the opportunities to build things from scratch. One student indicated, he "wanna do big things and turn small things into bigger things that can even bigger things." Among all the materials, the students often showed their interests in building Legos. One student mentioned that "with the Legos I can make it happen and without Legos I really can't."

Another common drive to have fun at makerspace was because they could "hang out with friends". In some cases, their personal interests in makerspace activities were imitated through friends. For instance, one student mentioned, "My friends are here. They were the ones that introduced me to the tech club so I got interested." Meanwhile, through participation at makerspace, they built new friendship, as one student commented "I'm friend with a lot of people because he introduced them to me."

In addition to having fun at makerspace, the students expressed that they could "be creative" and "experimental" with ideas and things and "see how it works". From the students' self-reports, the library makerspace offered a "very different" experience compared to what they did in the classroom. One student noted, 
"In other classes...we would either work alone together or when we take notes, the teacher would have on screen the paper and the underline part which was to fill in the notes and then you study on that... it just shows you what something does and it tells you that you have to make this out of that."

In the interviews, some students also indicated that participating at makerspace was due to their long-time individual interests in technologies and engineering, which they expected to further develop these interests through participation. The students also indicated that participating at makerspaces allowed them to develop identities as a tech-savvy and helpful person in their community. For example, one student responded that "I know what to do, so it would be really easy for me to jump in if someone else needs help I can help them because I have done it so." Another student commented, "Maybe one day I could help the community that I made out of technology."

\section{Questions encountered in makerspace activities}

The interviews, surveys, and the field observations show several categories of questions that the students encountered. The most common questions were about the processes of creation and building on computers. For example, the students were concerned with "how to type in all that stuff" when coding games, and "how to make the shapes and sizes and the cut outside of it' in 3D designing.

Following these process-oriented how-to questions, the students reported that they had questions regarding materials, online resources, and manuals. One student reported his questions on "how much of something do we need, what's useful, what's not" when working with the physical materials. When working on computers, one student had a question of "what do I want to make out of certain websites." Some other student commented on her confusions when trying to "understand what the book was saying."

Despite that the makerspace activities were largely informal and loosely structured, a few students reported their questions on the plans of their participation at makerspace. For instance, one student stated, "I usually question like so what are we going to do initially, what's the plan."

\section{Sense-making practices}

The interviews, surveys and filed observations show that the students employed a range of sense-making strategies to become informed when they encountered questions at makerspace. Overall, the most common practice was to tinker, and the least common practices were to consult authoritative and formal resources. Some other common practices included getting help from friends and peers as well as from computers.

Tinkering. When the students had questions and problems, they largely engaged in tinkering and became informed from their direct experiences through trial and error. For example, one 
student commented, "sometimes you have to start over, and rebuild it and start over again and rebuild it to figure out the right way to put it together." With a further analysis of their tinkering practices, it shows that the students often engaged making alternatives with available physical, digital, and/or conceptual resources. One student commented, "it's a lot of trial and error if we don't have the certain things to make out of it then we just move on to try something else or try to do the same thing but with different objects." Likewise, another student mentioned, "maybe like you can take one part and then put another part in it so it looks like it's just the same thing but it's not actually it".

During the tinkering practices, the students simultaneously used their bodies to become informed. A common term mentioned by the students was "to see" what worked out through testing. One student indicated that she "wanted to see what it would be like different you would change for coding, it's like turn 90 degrees, you can change it and have it turn the other way like 37 degrees or 84 degrees or something like that." Some other students stated, "I just keep switching things around and see if it works or not." Another student noted, "I can see if it works, with the Legos I can experiment with new things to see if it actually will work in real life, kinda look at the Legos as a model of it." This physical engagement in the process of knowing was also reflected on some students' visual preferences to the realness of their creations, especially when the students needed to evaluate and decide when their tinkering was good enough. For example, one student commented,

"If I were to take the 2 dimensional one and put it in, it would look like it's just flat, so if I put the 3D one when it's moving, it would look like it's all pixelated and would look like the real game so that's what l'm trying to get out of it."

Getting help from computers. Along with their practices of tinkering, the students also frequently turned to computers for help. The findings show that the computers mainly afforded three types of resources. A common practice was to utilize the resources available on the coding websites, such as following online tutorials. One student indicated that "most of time like they give you directions like tips to help you." Another student commented, "I'm trying to complete the second course and move on to the third course, so that way I don't accidently miss anything." Less frequently, the students engaged in the practice of playing games that were available on the coding websites. One student stated, "Playing extra games helps you get a feel of what you want to code and what you want to make out of certain websites."

In addition, the students sometimes used search engines to find pictures and videos that were helpful in their coding and creation. One student responded, "I looked up ideas such as on YouTube and then searched on it."

Only two students indicated that they revisited their previous works for help. One student explained, "if I made something that I really like, then I would like to save it as a picture so that I can remember it, so if I want to make it again I can from a picture." 
Getting help from friends and peers. Following the practices of tinkering and seeking help from computers, the students frequently sought help from their friends and peers at makerspace. In many occasions, the students asked for help by identifying expertise among their friends. One student commented, "they know a little bit more than us and maybe they can give us some knowledge on what we are doing wrong." They also sought help from whoever was conveniently available. Some students identified that people "sitting next to me" to help them. Sometimes, they got helped as their friends actively offered helps. One student stated, "I kept trying over and over and then my friend came over and she helped me with it." In addition to communicating with their friends and peers, materials at hand and computers played an important role in mediating and facilitating their interactions. For example, one student explained "he used my mouse to show me on my screen of how to use it like where to put it."

Getting help from authoritative and formal sources. Compared to the students' preference of seeking help from their direct experience of tinkering with the materials and computers, they occasionally asked the teacher for help as one student indicated, "they would know what they are doing." Also, only a small number of students followed books and manual in their making activities.

\section{Barriers in information practices}

Several barriers that hindered the students from knowing and getting answers were emerged from the interviews, surveys and field observations. The most common barrier was pertaining to materials, such as having broken and limited materials, and vague instructions on the toolkits. For instance, one student commented,

"The Little Bits, they were like a little hard because they didn't have anything written on them or anything so it's the color and the way it looks that you have to know and I didn't really know what went with what so that was hard."

When the students worked on computers, they reported that vague video tutorials were not helpful. One student reported, "Sometimes when the video coding thing sometimes they introduce new things but they don't really talk about it, they talk about something else that you probably already know." In addition, some students indicated that a limited access to websites stopped them from getting ideas of their game designing, either due to the block of certain websites by the school or the unavailability of external websites. For instance, one student commented,

"I wanted to go on this website. It's called Minecraft and the teacher said that we could only do coding and I asked him why couldn't we and he was like because this club was for coding and makerspace and stuff like that." 
However, this student later reported his reactions to such a constraint, "but if you can create a game of it for other kids to play, which is kinda bending the rules but you can still play Minecraft without being in trouble."

The findings also show that the students occasionally encountered limited interpersonal helps. For example, one student commented, "cause the kids are always like busy doing their own stuff and sometimes they don't finish answering the questions, they are like going back to do their own things." The set of data further reveals that the students did not seek help from the teacher was due to their negative perception of authority, as one student commented, "I didn't think he knew." Occasionally, the students reported that they just gave up further problem solving and sense-making because "it wasn't that big of a deal."

\section{Discussion}

By using a hybrid theoretical framework of Dervin's Sense-Making theory and sociocultural theories to learning, this study teases out what drove the middle school students to their school library makerspace and how they made sense of their activities of making and doing at makerspace. Through using two rounds of interviews, Sense-Making surveys, and field observations over six months, this study's findings have shown that the school library makerspace was an information-rich social and informal learning setting for the students to engage in interdisciplinary inquiries and discoveries, especially in science, technologies, engineering, mathematics and arts. This finding supports the argument that libraries are not just places of curating; with the popularity of digitalization and "everything is available on Google" (Hawkins, 2015, p.25), school library makerspace can be a place for students to have fun, be creative, tinker, and develop their interests as well as skills in science, arts, humanities, media, music, and sports.

The study shows that the school students' information practices were social in nature as they frequently sought help from interpersonal interactions. This was consistent with the findings in previous research on young people's everyday life information seeking (Agosto \& Hughes-Hassell, 2006; Dresang, Gross, \& Holt, 2003; Shenton \& Dixon, 2005). Additionally, the finding that the students less frequently used authoritative and formal information sources was align with previous research (e.g., Julien, 1999; Meyers, Fisher, \& Marcoux, 2009). Further, this study shows that help seeking from interpersonal interactions was mediated by questions and ideas, which served as shared epistemic objects during the students' collaborative sense-making. Shared space, tools, and materials available were also intertwined in the students' collaborative sense-making. Thus, this study further contributes to the body of literature on young people's information practices in informal space by highlighting the materials and tools available in the space as an important role in affording the social aspects of information practices. 
The findings show that the students mostly engaged in tinkering with ideas and materials to make sense of problems and questions - a process of involving not just mental activities but also sensory and embodied experiences with materials and tools. The materials and tools at library makerspace shaped the students' learning and problem-solving experience, which in turn shaped epistemic and material resources available in the space. The findings contribute to the emerging discussion on embodied ways of knowing in information science (Anderson, 2007), and support a holistic view on sense-making process (Olsson, 2010), suggesting that information practices are intertwined with social activities, embodiment, and materials in an informal learning setting.

The barriers reported in this study indicated unnegotiable aspects of the library makerspace, such as broken materials, limited access to websites that was controlled by the school, and limited expertise among their peers. Yet, the students responded to these constraints with making alternative plans, creating replacement by themselves, or giving up further sense-making. These interplays between the constraints and the students' activities made up the contexts of their information practices, indicating their dialectical shaping relationship between practices and structure (Anderson, 2007; Lave, 1988). Overall, the school library makerspace can be seen as a collaborative social entity embedded in a formal educational institution that follows professional practices and structures.

The findings of this study have several implications for information professionals working with students at school library makerspaces: 1) supports and helps are needed during the initial design and actual making phases, 2) an informal and supportive learning environment of a library makerspace affords students to experiment their ideas and develop skills, 3) students should be encouraged to question about materials, tools and ideas, and engage in tinkering with materials and tools as well as consulting social resources.

\section{References}

Agosto, D. E., \& Hughes-Hassell, S. (2006). Toward a model of the everyday life information needs of urban teenagers, part 2: empirical model. Journal of the American Society for Information Science, 2(11), 1418-1426. doi:10.1002/asi

Anderson, T. D. (2007). Settings, arenas and boundary objects: socio-material framings of information practices. In Proceedings of the Sixth International Conference on Conceptions of Library and Information Science- "Featuring the Future" (Vol. 12, pp. $1-7)$.

Ash, D. (2007). Using video data to capture discontinuous science meaning making in non-school settings Doris. In \& S. J. D. R. Goldman, R. Pea, B. Barron (Ed.), Video research in the learning sciences (pp. 207-226). Routledge.

Bell, P., Lewenstein, B., Shouse, A. W., \& Feder, M. A. (2009). Learning science in informal 
environments: People, places, and pursuits". (P. Bell, B. Lewenstein, A. W. Shouse, \& M. A. Feder, Eds.)The Journal of Environmental Education (Vol. 43). Washington, DC: The National Academies Press. doi:10.1080/00958964.2011.623734

Benton, C., Mullins, L., Shelley, K., \& Dempsey, T. (2013). Makerspaces: Supporting an entrepreneurial system.

Bowler, L. (2014). Creativity through "Maker" Experiences and Design Thinking in the Education of Librarians. Knowledge Quest, 42(5), 58-61. Retrieved from https://login.proxy.libraries.rutgers.edu/login?url=http://search.ebscohost.com/login.asp $x$ ?direct=true $\& \mathrm{db}=$ eric $\& A N=E J 1041897 \&$ site=eds-live

Brendlinger, N., Dervin, B., \& Foreman-wernet, L. (1999). When respondents are theorists: An exemplar study in the HIVIAIDS context of the use of sense-making as an approach to public communication campaign audience research. The Electronic Journal of Communication, 9(2), 1-23.

Cole, M., \& Engeström, Y. (1993). A cultural-historical approach to distributed cognition. In G. Salomon (Ed.), Distributed cognitions: Psychological and educational considerations (pp. 1-46). Cambridge, England: Cambridge University Press.

Colegrove, T. (2013). Editorial board thoughts: Libraries as makerspace ? Information Technology and Libraries, 32(1), 2-5.

Courtright, C. (2007). Context in information behavior research. Annual Review of Information Science and Technology, (41), 273-306.

Creswell, J. W. (2003). Research design: Qualitative, quantitative, and mixed methods approaches (2nd ed.). Thousand Oaks, CA: SAGE Publications, Inc.

Dervin, B. (1992). From the mind's eye of the user: The sense-making qualitative quantitative methodology. In Qualitative research in information management (pp. 61-84).

Dervin, B. (1998). Sense-making theory and practice: an overview of user interests in knowledge seeking and use. Journal of Knowledge Management, 2(2), 36-46. doi:10.1108/13673279810249369

Dervin, B. (1999). On studying information seeking methodologically: the implications of connecting metatheory to method. Information Processing \& Management, 35(6), 727-750. doi:10.1016/S0306-4573(99)00023-0

Dervin, B., \& Nilan, M. (1986). Information needs and uses. Annual Review of Information Science and Technology (ARIST), 21, 3-33.

Dresang, E. T., Gross, M., \& Holt, L. E. (2003). Project CATE Using outcome measures to assess school-age children's use of technology in urban public libraries. Library \& 
Information Science Research, 25(1), 19-42. doi:10.1016/S0740-8188(02)00164-0

Falk, J. H., \& Dierking, L. D. (2000). Learning from museums: An introduction. In Learning from museums (pp. 1-14). Walnut Creek, CA: AltaMira Press.

Fontichiaro, K. (2014). Makerspaces: Inquiry and CCSS. School Library Monthly, 30(6), 48-49. Retrieved from

http://search.ebscohost.com/login.aspx?direct=true\&db=Ils\&AN=97266179\&site=ehost-I ive\&scope=site

Gans, H. J. (1999). Participant observation in the era of "ethnography." Journal of Contemporary Ethnography, 28(5), 540-548. doi:10.1177/089124199129023532

Genuis, S. K. (2012). Constructing "sense" from evolving health information: A qualitative investigation of information seeking and sense making across sources. Journal of the American Society for Information Science and Technology, 63(8), 1553-1566. doi:10.1002/asi.22691

Glaser, B. G., \& Strauss, A. L. (1967). The discovery of grounded theory: Strategies for qualitative research. New York: Aldine Publishing Corporation.

Godbold, N. (2013). An informational need for emotional clues: Unpacking the role of emotions in sensemaking. Information Research, 18(1).

Graves, C. (2014). What Is a Makerspace? Knowledge Quest, 42(4).

Gustafson, E. (2013). Meeting Needs: Makerspaces and school libraries. School Library Monthly, 29(8), 35-36. Retrieved from http://search.ebscohost.com/login.aspx?direct=true\&db=Ils\&AN=87773562\&site=ehost-I ive\&scope=site

Hakkarainen, K., Paavola, S., Kangas, K., \& Seitamaa-Hakkarainen, P. (2013). Sociocultural perspectives on collaborative learning: Toward collaborative knowledge creation. In C. E. Hmelo-Silver, C.A. Chinn, C. K. K. Chan \& A. M. O'Donnell (Eds.), The international handbook of collaborative learning (57-73). New York, NY: Routledge/Taylor \& Francis.

Hawkins, D. (2015). Making and community engagement in the library, 32(8).

Hsi, S. (2004). Models of Learning and Theories of Practice for Informal Learning Environments, 1-8.

Hutchins, E. (1995). Cognition in the wild. Cambridge, MA: MIT Press.

Julien, H. (1999). Barriers to adolescents' information seeking for career decision making. Journal of the American Society for Information Science, 50(1), 38-48. doi:10.1002/(SICI)1097-4571(1999)50:1<38::AID-ASI6>3.0.CO;2-G 
Kawulich, B. B. (2005). Forum: Qualitative social research participant observation as a data collection method. Qualitative Social Research Journal, 6(2), 28.

Kincheloe, J. L. (2001). Describing the bricolage: Conceptualizing a new rigor in qualitative research. Qualitative Inquiry, 7(6), 679-692. doi:10.1177/107780040100700601

Koh, K. (2015). Are they really learning? A case study of a school library makerspace.

Lave, J. (1988). Cognition in practice: Mind, mathematics and culture in everyday life. Cambridge University Press.

Lave, J., \& Wenger, E. (1991). Situated learning: Legitimate peripheral participation (Vol. 2, pp. 13-58).

Meyers, E. M., Fisher, K. E., \& Marcoux, E. (2009). Making sense of an information world: The everyday-life information behavior of preteens. Library Quarterly, 79(3), 301-341.

Miles, M. B., Huberman, A. M., \& Saldaña, J. (2013). Qualitative data analysis: A methods sourcebook. SAGE Publications, Incorporated.

Olsson, M. (2010). The play's the thing: Theater professionals make sense of Shakespeare. Library \& Information Science Research, 32(4), 272-280. doi:10.1016/j.lisr.2010.07.009

Shapiro, L. (2010). Embodied cognition. Routledge.

Savolainen, R. (1995). Everyday life information-seeking: Approaching information-seeking in the context of way of life. Library \& Information Science Research, 17, 259-294.

Shenton, A. K., \& Dixon, P. (2005). Information needs: Learning more about what kids want, need, and expect from research. Children and Libraries, 20-29.

Vygotsky, L. S. (1980). Mind in society: The development of higher psychological processes. Harvard university press.

Biographical note

Author 1: Xiaofeng $\mathrm{Li}$ is a $\mathrm{PhD}$ candidate in the Department of Library and Information Science at Rutgers, The State University of New Jersey. Her research interests include children and adolescents' information practices and learning in informal contexts, as well as the role of these informal learning environments in children and adolescents' development.

Author 2: Dr Ross J. Todd is professor and chair of the Department of Library and Information Science at Rutgers, The State University of New Jersey, and Director of the Center for International Scholarship in School Libraries. His research focuses on how students learn in digital environments, and how school librarians can engage with evidence-based practices to ensure the on-going development of school libraries to meet the needs of students in $21^{\text {st }}$ schools. 